Article

\title{
Process Optimization of Waste Activated Sludge in Anaerobic Digestion and Biogas Production by Electrochemical Pre-Treatment Using Ruthenium Oxide Coated Titanium Electrodes
}

\author{
Gan Chin Heng $1, * \mathbb{C}$, Mohamed Hasnain Isa ${ }^{2}$, Serene Sow Mun Lock ${ }^{3}\left(\mathbb{D}\right.$ and Choon Aun $\mathrm{Ng}^{4}$ \\ 1 Department of Civil Engineering, Lee Kong Chian Faculty of Engineering and Science, \\ Universiti Tunku Abdul Rahman, Jalan Sungai Long, Bandar Sungai Long, Cheras, \\ Kajang 43000, Selangor, Malaysia \\ 2 Civil Engineering Programme, Faculty of Engineering, Universiti Teknologi Brunei, Tungku Highway, \\ Gadong BE1410, Brunei; mohamed.isa@utb.edu.bn \\ 3 CO2 Research Center (CO2RES), Department of Chemical Engineering, Universiti Teknologi PETRONAS, \\ Seri Iskandar 32610, Perak, Malaysia; sowmun.lock@utp.edu.my \\ 4 Department of Environmental Engineering, Faculty of Engineering and Green Technology, \\ Universiti Tunku Abdul Rahman, Jalan Universiti, Bandar Barat, Kampar 31900, Perak, Malaysia; \\ ngca@utar.edu.my \\ * Correspondence: ganch@utar.edu.my
}

\section{check for} updates

Citation: Heng, G.C.; Isa, M.H.; Lock, S.S.M.; Ng, C.A. Process Optimization of Waste Activated Sludge in Anaerobic Digestion and Biogas Production by Electrochemical Pre-Treatment Using Ruthenium Oxide Coated Titanium Electrodes. Sustainability 2021, 13, 4874 https://doi.org/10.3390/su13094874

Academic Editor: Andreas N. Angelakis

Received: 22 February 2021

Accepted: 23 March 2021

Published: 27 April 2021

Publisher's Note: MDPI stays neutral with regard to jurisdictional claims in published maps and institutional affiliations.

Copyright: (c) 2021 by the authors Licensee MDPI, Basel, Switzerland. This article is an open access article distributed under the terms and conditions of the Creative Commons Attribution (CC BY) license (https:/ / creativecommons.org/licenses/by/ $4.0 /)$.

\begin{abstract}
Anaerobic digestion (AD) appears to be a popular unit operation in wastewater treatment plant to treat waste activated sludge (WAS) and the produced methane gas can be harvested as renewable energy. However, WAS could inhibit hydrolysis stage during AD and hence pre-treatment is required to overcome the issue. This paper aimed to study the effect of electrochemical pretreatment $(\mathrm{EP})$ towards efficiency of $\mathrm{AD}$ using titanium coated with ruthenium oxide $\left(\mathrm{Ti} / \mathrm{RuO}_{2}\right)$ electrodes. The investigation has been carried out using in-house laboratory batch-scale mesophilic anaerobic digester, mixed under manipulation of important operating parameters. Optimization was performed on EP using response surface methodology and central composite design to maximize sludge disintegration and dewaterability. By operating at optimal conditions $(\mathrm{pH} 11.65$, total solids $22,000 \mathrm{mg} / \mathrm{L}$, electrolysis time $35 \mathrm{~min}$, current density $6 \mathrm{~mA} / \mathrm{cm}^{2}$, and $1000 \mathrm{mg} / \mathrm{L}$ of sodium chloride), the pre-treated WAS in terms of mixed liquor volatile suspended solids (MLVSS) removal, soluble chemical oxygen demand (sCOD), capillary suction time (CST) reduction, and extracellular polymeric substance (EPS) were 38\%, $4800 \mathrm{mg} / \mathrm{L}$ (increased from $935 \mathrm{mg} / \mathrm{L}$ ), 33\%, and $218 \mathrm{mg} / \mathrm{L}$, respectively. Following AD, the volatile solids (VS) removal and chemical oxygen demand (COD) removal by EP were enhanced from $40.7 \%$ and $54.7 \%$ to $47.2 \%$ and $61.5 \%$, respectively, at steady-state. The biogas produced from control and electrochemical pre-treated WAS were in the ranges of 0.12 to 0.17 and 0.2 to $0.24 \mathrm{~m}^{3} / \mathrm{kg} \mathrm{VS}_{\text {fed }}$, respectively, and the volume of biogas produced was $44-67 \%$ over the control. Based on the results obtained, suitability of EP for WAS prior to AD was confirmed.
\end{abstract}

Keywords: biogas; electrochemical process; mesophilic anaerobic digestion; response surface methodology; titanium coated with ruthenium oxide $\left(\mathrm{Ti} / \mathrm{RuO}_{2}\right)$; waste activated sludge

\section{Introduction}

Biological treatment is a common method applied in most wastewater treatment plants (WWTP). During treatment of municipal wastewater, waste activated sludge (WAS) is produced in huge amounts as a by-product, with the total solids concentration varying between 0.8 and $1.2 \%$ [1]. The transportation, treatment and disposal of WAS is an important issue as it adds to the overall cost of wastewater treatments, as well as for sludge management $[2,3]$. Therefore, an efficient sludge treatment strategy is highly desired to minimize its volume and reduce the WWTP operating cost. 
Anaerobic digestion could diminish domestic wastewater sludge solids by $30-50 \%$, and at the same time produce methane gas $\left(\mathrm{CH}_{4}\right)$. The $\mathrm{CH}_{4}$ gas can be converted to energy and offset part of the operating cost of WWTP [4]. WAS has low biodegradability and requires long retention time for anaerobic digestion. Extracellular polymeric substances (EPS) that exist in WAS hinder sludge hydrolysis [5]. EPS consists of two major organic components viz., proteins and polysaccharides [6]. It has high water binding properties [7-9] and represents up to $80 \%$ of the mass of WAS [10]. Pre-treatment, such as using photo-Fenton process [11], biological hydrolysis [12], and an electrochemical process [13] is required to degrade EPS in order to improve WAS disintegration and digestibility by turning large organic materials into smaller, biodegradable components. Increasing relatively low levels of EPS can aid sludge dewaterability by improving the level of sludge flocculation [14]. This reduces the number of small particles present in the sludge, a factor that has been shown previously to make the sludge easier to dewater [15]. Capillary suction time (CST) is an indicator to measure the dewaterability of sludge.

Electrochemical process has been shown to be a promising method for wastewater treatment. Furthermore, electrochemical treatment is versatile and can be applied to different type of wastewaters. It is also environmentally benign as it does not produce secondary pollutants after treatment. In electrochemical processes, it is aimed to increase the degradability of the influent waste sludge, which results in enhancement of anaerobic digestion efficiency. Ruthenium oxide $\left(\mathrm{RuO}_{2}\right)$ anode is one of the mixed metal oxides (MMO) which has relatively long lifetime, high electro-catalytic activity, low cost and is suitable for industrial utilization $[16,17]$. The use of $\mathrm{Ti} / \mathrm{RuO}_{2}$ electrode has been demonstrated to be effective in the treatment of various type of effluents, such as produced water [18], wastewaters from petroleum industry [19], and textile wastewater [20]. Biopolymeric substances were disintegrated to smaller and biodegradable fractions, and the treatment efficiency of subsequent biological treatment was enhanced [13,21].

The working principal of electrochemical process using $\mathrm{Ti} / \mathrm{RuO}_{2}$ anode is shown in Reaction (1), in which water molecules are oxidized that yields physiosorbed hydroxyl radicals $(\bullet \mathrm{OH})$. At the anode surface, interaction between the metal oxide and $\bullet \mathrm{OH}$ generates an electrode with higher oxidizing power as depicted in Reaction (2).

$$
\begin{gathered}
\mathrm{RuO}_{2}+\mathrm{H}_{2} \mathrm{O} \rightarrow \mathrm{RuO}_{2}(\bullet \mathrm{OH})+\mathrm{H}^{+}+\mathrm{e}^{-} \\
\mathrm{RuO}_{2}(\bullet \mathrm{OH}) \rightarrow \mathrm{RuO}_{3}+\mathrm{H}^{+}+\mathrm{e}^{-}
\end{gathered}
$$

Subsequently, pollutants $(\mathrm{P})$ can be oxidized through redox reactions of $\mathrm{RuO}_{3} / \mathrm{RuO}_{2}$ as demonstrated in Reaction (3). Nonetheless, the oxidized electrode can also be decomposed simultaneously through the oxygen evolution by-reaction, as depicted in Reaction (4) [22-24].

$$
\begin{gathered}
\mathrm{RuO}_{3}+\mathrm{P} \rightarrow \mathrm{RuO}_{2}+\mathrm{PO} \\
2 \mathrm{RuO}_{3} \rightarrow 2 \mathrm{RuO}_{2}+\mathrm{O}_{2}
\end{gathered}
$$

(Reaction 3)

(Reaction 4)

We have previously conducted a preliminary study on WAS disintegration by $\mathrm{Ti} / \mathrm{RuO}_{2}$ electrodes under the influence of several operating conditions and demonstrated effectiveness of the electrochemical process [25]. Yu et al. (2014) conducted research on treating WAS via electrochemical approach through utilization of $\mathrm{Ti} / \mathrm{RuO}_{2}$ electrodes aided with hypochlorite, and compared its performance with conventional methodology [26]. It was demonstrated in their study that the electrochemical pretreatment was able to enhance degradation of organic matter by $38.1 \%$ and biogas production by $63.4 \%$. Nonetheless, the study has been devoted to mere comparison between electrochemical and conventional pre-treatment at a base operating condition, while elucidation on the effect of important process variables has not been focus such as to study the effect of concentration of EPS and CST reduction on sludge disintegration and dewaterability. A later study of Ye et al. (2016) further reaffirmed the feasibility of using $\mathrm{Ti} / \mathrm{RuO}_{2}$ anode in electrochemical pre-treatment aided with hypochlorite while extending the study through manipulation in concentration 
of $\mathrm{ClO}^{-}$. The authors reported enhanced methane production by $61.1 \%$ compared to the control, at an optimal dosage of $0.6 \%(v / v)$ hypochlorite [27]. In a recent study by Erden (2019), he performed a comparison and process optimization of electro-oxidation process towards disintegration degree (DD) of biological sludge through adaptation of varying electrode (viz. Ti and $\mathrm{Ti} / \mathrm{RuO}_{2}$ ) pairs. DD was selected as the system response, with voltage and time being the process variables to be varied [28]. In another current work by Ajab et al. (2020), the $\mathrm{Ti} / \mathrm{RuO}_{2}$ anodes was further coated with $\mathrm{RuCl} 3 \times \mathrm{H} 2 \mathrm{O}$ solutions of varying concentrations to be applied in degradation of 16 priority polycyclic aromatic hydrocarbons (PAH). The authors found that the optimal condition was obtained under medium precursor solutions concentration (0.8 M) [29].

Based on a review of published literatures, it is found that solubilization of pollutants through utilization of $\mathrm{Ti} / \mathrm{RuO}_{2}$ electrodes is found to be a promising process. Studies have been emerging to elucidate the effect of varying process variables towards the WAS degradation process, which reaffirms that an electrochemical process is highly dependent upon operating conditions. It is seen that there has been a shift towards improvement of the electrochemical process through additional coating or a precursor solution over recent years. However, a majority of the studies have been devoted to evaluation of electrochemical pre-treatment for the digestion of contaminants using laboratory scale investigations in a qualitative manner. In fact, quantification of interactions between process inputs and outputs are actually important to enhance the understanding of the process. The investigation is typically required if the process factors inherit significant relationships between one another, which results in strongly non-linear correlations, and is complicated to be elucidated via mere experimental observation. In this context, the works devoted to quantification of process variables in electrochemical pre-treatment in anaerobic digestion have been limitedly reported to date. In addition, process optimization of biological sludge's disintegration using only $\mathrm{Ti} / \mathrm{RuO}_{2}$ electrodes via employment of correlation with high precision has to be performed prior to improvement of the electrochemical process to gain effective insight underlying the process. Albeit acknowledgement on the importance of optimization towards pollutant's degradation under the influence of varying operating parameters, the number of research studies are still scarcely available. Among the limited work, the recent study by Erden [28] is included. Nonetheless, merely two manipulated variables have been studied (e.g., voltage and time) with the ultimate response confined to DD. In addition, it is found that majority of the studies have been limited to only study up to solubilization of waste, while electrochemical treatment for improvement of biogas production has received less scrutiny [26].

Therefore, the objectives of this paper were: (1) to perform process quantification and optimization of essential operating parameters, determined from our previous study [25], towards WAS disintegration and dewaterability of $\mathrm{Ti} / \mathrm{RuO}_{2}$ electrochemical treatment, and (2) to study the effect of operating $\mathrm{Ti} / \mathrm{RuO}_{2}$ electrochemical pre-treatment at optimal variables on anaerobic digestion and biogas production of WAS. Novelty of this work lies on process quantification of four dependent variables, such as Mixed Liquor Volatile Suspended Solids (MLVSS) removal, soluble Chemical Oxygen Demand (sCOD), Capillary Suction Time (CST) reduction, and Extracellular Polymeric Substance (EPS) [30,31], with respect to influence of four important and interacting operating conditions, which includes initial $\mathrm{pH}$ value of sludge, sludge concentration, electrolysis time and current density. In this work, response surface methodology (RSM) was used to quantify the effect of four main variables: $\mathrm{pH}$ of the sludge sample, sludge concentration, electrolysis time, and current density on the four dependent variables: MLVSS removal, sCOD, CST reduction, and EPS, which represent the sludge's disintegration and dewaterability, that reflect efficiency of WAS pre-treatment. RSM has been selected since it is able to generate precise results at the expense of reduced experimental works in comparison to the conventional one-factorat-a-time approach and full-factorial design [32]. Central composite design (CCD) has been chosen as the design matrix because it enables valid recognition of the first-order variables' interaction and gives a second-order polynomial model to predict the optimum 
operating conditions of the selected parameters [33]. The RSM models have been employed to determine the optimal influencing conditions, which have been subsequently adapted to proceed with study of anaerobic digestion for biogas production.

\section{Materials and Methods}

\subsection{Sample Preparation and Electrode Coating}

In the present study, WAS was gained from the secondary clarifier of a sewage treatment plant located at the Universiti Teknologi PETRONAS campus. The WAS samples were concentrated by settling and kept at $4{ }^{\circ} \mathrm{C}$ in a cold room before being used. Table 1 presents the properties of the raw WAS averaged from three samples.

Table 1. Properties of waste activated sludge (WAS).

\begin{tabular}{cc}
\hline Parameter & Mean Value (Standard Deviation) \\
\hline $\mathrm{pH}$ & $7.02( \pm 0.02)$ \\
Total solids $(\mathrm{mg} / \mathrm{L})$ & $41,500( \pm 1301)$ \\
Volatile solids (mg/L) & $26,020( \pm 572)$ \\
Mixed liquor suspended solids (mg/L) & $38,057( \pm 1052)$ \\
Mixed liquor volatile suspended solids (mg/L) & $25,371( \pm 387)$ \\
Total chemical oxygen demand (mg/L) & $35,850( \pm 271)$ \\
Soluble chemical oxygen demand (mg/L) & $935( \pm 21)$ \\
Capillary suction time (s) & $114( \pm 9)$ \\
Extracellular polymeric substances (EPS) $(\mathrm{mg} / \mathrm{L})^{1}$ & $370( \pm 12)$ \\
\hline
\end{tabular}

${ }^{1}$ EPS comprises of total protein and polysaccharides.

Pechini's methodology was employed for the preparation of $\mathrm{RuO}_{2}$ coating on a pair of titanium plate electrodes, with an effective electrode area of $43.65 \mathrm{~cm}^{2}[25,34]$. The coating solution was prepared from analytical grade citric acid, propanol and ruthenium (II) chloride dehydrate in the molar ratio of 3:10:1.

\subsection{Experimental Procedures and Statistical Analysis}

Electrochemical pre-treatment was conducted in a $1 \mathrm{~L}$ glass beaker through adaptation of $\mathrm{Ti} / \mathrm{RuO} 2$ electrodes in pair. The electrical current was supplied by a power unit with a constant voltage of $20 \mathrm{~V}$. Yuan et al. [35] reported that optimal electrolysis voltage to be in the range of 15 to $20 \mathrm{~V}$ [35], while Erden [28] found $20 \mathrm{~V}$ as the most effective condition to be applied for the electrode couples [28]. The sludge samples were stirred gently during the experiments to avoid sludge settling and were collected for measurement of MLVSS, SCOD, CST, and EPS.

Design Expert software (version 6.0.7) was employed to design the experiments. RSM and CCD were used to the quantify the effect of four main variables: $\mathrm{pH}$ of the sludge sample, sludge concentration, electrolysis time, and current density on WAS pretreatment. Subsequently, it can be used to determine optimal operating conditions of the electrochemical process for the ultimate goal in improving sludge disintegration and dewaterability. Table 2 shows the study ranges which were chosen based on our preliminary results [25].

Table 2. Independent variables and their levels for the CCD used for electrochemical process.

\begin{tabular}{ccccccc}
\hline \multirow{2}{*}{ Independent Variable } & & \multicolumn{5}{c}{ Levels and Ranges (Coded) } \\
\cline { 3 - 7 } & Code & $\mathbf{- 1 . 6 8}$ & $-\mathbf{1}$ & $\mathbf{0}$ & $\mathbf{1}$ & $\mathbf{1 . 6 8}$ \\
\hline $\mathrm{pH}$ & $\mathrm{A}$ & 9 & 10 & 11 & 12 & 13 \\
Sludge concentration $(\mathrm{mg} / \mathrm{L})$ & $\mathrm{B}$ & 10,000 & 15,000 & 20,000 & 25,000 & 30,000 \\
Electrolysis time $(\mathrm{min})$ & $\mathrm{C}$ & 10 & 20 & 30 & 40 & 50 \\
Current density $\left(\mathrm{mA} / \mathrm{cm}^{2}\right)$ & $\mathrm{D}$ & 2.5 & 5 & 7.5 & 10 & 12.5 \\
\hline
\end{tabular}


The response data were analyzed using Design Expert software (version 6.0.7) to determine the effects of model terms. The optimum operating conditions were established using an overlay plot by setting the minimum and maximum permissible values. After electrochemical pre-treatment, the initial $\mathrm{pH}$ of sludge samples was adjusted to 7 with $\mathrm{H}_{2} \mathrm{SO}_{4}$ solution and stored at $4{ }^{\circ} \mathrm{C}$ before being subjected to anaerobic digestion.

Anaerobic digestion was conducted within two similar bench-scale reactors operated at batch-fed and perfectly mixed conditions through agitation at $120 \mathrm{rpm}$. Each of the digesters consists of sludge feeding and sampling ports for addition and removal of substrate. Pre-treated and untreated WAS were fed into the reactors daily to make comparison between digestibility of the sludge. The inoculum was obtained from a local municipal WWTP, which utilizes sequencing batch reactor (SBR) for anaerobic digestion of the wastewater. The thickened WAS was digested with a Sludge Retention Time (SRT) of 15 days regulated at mesophilic temperature of $37 \pm 0.5^{\circ} \mathrm{C}$. Quantity of seed to be added was approximated to be 20 times the amount of anticipated volatile solids in the raw WAS according to United States Environmental Protection Agency (USEPA) [36]. Each of the digesters (2 L working volume) was flushed with nitrogen gas to ensure an oxygen-free environment. Throughout the process, the digestion was observed tightly to safeguard that a steady-state condition was been maintained with daily fluctuation in COD decrement being continuously $<10 \%$. Collection of samples was carried out daily for solid and COD measurement whereas biogas $\left(\mathrm{CH}_{4}\right.$ and $\left.\mathrm{CO}_{2}\right)$ measurements were conducted two times per week.

\subsection{Analytical Methodology}

Solids, which encompass total solids, volatile solids, mixed liquor suspended solids, and mixed liquor volatile suspended solids, were determined in accordance with Standard Methods [37]. COD was determined by the Reactor Digestion HACH Method No. 8000 [38]. The dewaterability of sludge was determined by measuring its capillary suction time (CST) using Triton type 319 Multi-CST (Triton Electronics Ltd., Dunmow, UK). EPS, which is made up of two major components (protein and polysaccharides), were extracted by Triton methodology $[39,40]$ and determined as total summation of them. Protein concentration was determined by the Bicinchoninic acid (BCA) methodology [40], and polysaccharides concentration was determined by sulfuric acid-UV approach [41]. The biogas production rate was recorded during scheduled routine through measurement of water volume displaced in a cylinder connected to the digester. With regards to determination of biogas composition (methane and carbon dioxide), a gas chromatograph (PerkinElmer ${ }^{\circledR}$ Clarus $^{\circledR}$ 580 GC) with dual thermal conductivity detector (TCD) and packed column (7' Hayesep N 60/80, 1/8" Sf; 9' Molecular Sieve $13 \times 45 / 60$ Sf; 9' Molecular Sieve 5A 45/60 Sf; 4' HayeSep T 60/80 Sf) was adapted. Chromatograms were produced via the PerkinElmer's refinery gas test mix with part number N6107198.

\section{Results and Discussion}

\subsection{Disintegration and Dewaterability of WAS by Electrochemical Pre-Treatment}

In this section, the disintegration and dewaterability characteristics of WAS through the pre-treatment process were analyzed and discussed. In this context, the effect of four important process variables discussed in our previous study, such as $\mathrm{pH}$, sludge concentration, electrolysis time, and current density, towards four important indicators of the disintegration and dewaterability properties, viz. MLVSS removal, sCOD concentration, CST reduction, and EPS concentration, were provided quantitatively. Subsequently, process optimization was performed in which the four operating parameters were optimized to determine the most suitable operating conditions for disintegration and dewaterability of WAS. 


\subsubsection{Process Analysis}

Experimental data were evaluated using approximating functions of four dependent variables viz., MLVSS removal $\left(Y_{1}\right)$, sCOD concentration $\left(Y_{2}\right)$, CST reduction $\left(Y_{3}\right)$ and EPS concentration $\left(\mathrm{Y}_{4}\right)$. Equations (1)-(4) are the corresponding model equations obtained from CCD. A, B, C, and D are independent variables that correspond to $\mathrm{pH}$, sludge concentration, electrolysis time and current density, respectively. The ANOVA $m$ for $Y 1$ to $Y 4$ of the quadratic model were attached in Tables S1-S4, respectively, in the Supplementary Material.

$$
\begin{gathered}
Y_{1}=16.31+8.04 A+3.99 B+1.15 C+0.37 D+1.99 A^{2}-0.44 B^{2}-1.02 C^{2} \\
+0.75 D^{2}-1.27 A B+0.64 A C-0.068 A D+0.30 B C+0.17 B D+0.49 C D \\
Y_{2}=4299.63+2026.34 A+529.81 B-464.65 C+60.43 D+115.46 A^{2}-489.79 B^{2}+250.91 C^{2} \\
+327.29 D^{2}+829.37 A B+76.97 A C+66.82 A D+92.36 B C+46.41 B D-92.27 C D \\
Y_{3}=40.79-9.32 A-3.94 B-1.26 C-0.25 D-11.96 A^{2}+3.18 B^{2}-0.057 C^{2}+ \\
3.16 D^{2}-3.64 A B+0.23 A C-0.68 A D-0.11 B C+0.34 B D+0.34 C D \\
Y_{4}=266.78+97.66 A+44.53 B+30.48 C+9.19 D+52.10 A^{2}-4.08 B^{2}+23.87 C^{2}-16.3 D^{2}+ \\
42.31 A B+6.58 A C+1.49 A D-29.80 B C+5.00 B D+2.83 C D
\end{gathered}
$$

The four equations show that $\mathrm{pH}(\mathrm{A})$ has the highest weightage of single effect among all four operating parameters; followed by sludge concentration (B), electrolysis time (C) and current density (D). The two most significant interactive effects ( $\mathrm{pH}$ and sludge concentration) of the electrochemical pre-treatment are illustrated as three-dimensional response surface plots in Figure 1.

(a)

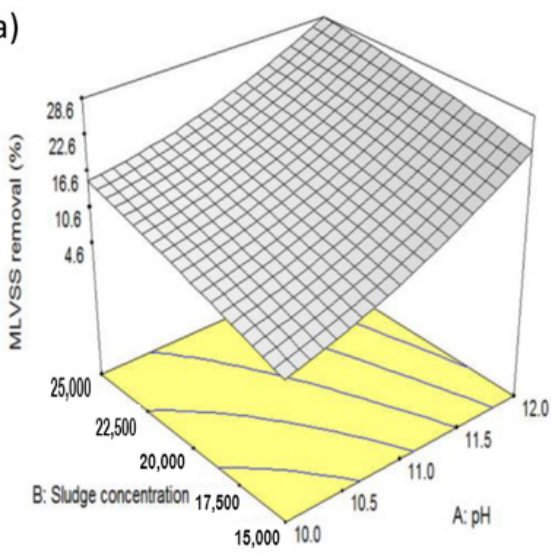

(c)

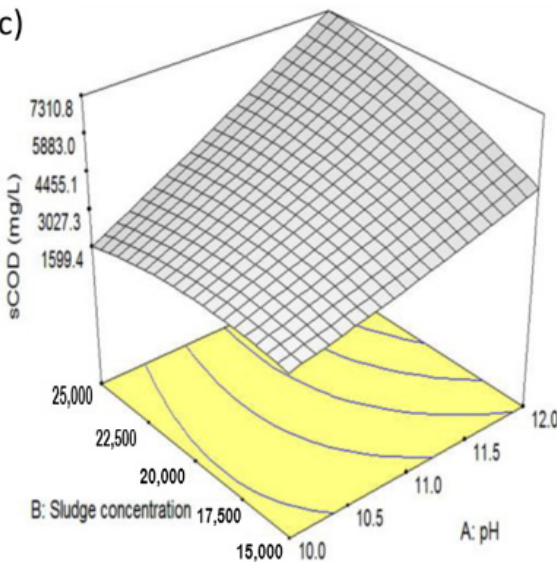

(b)
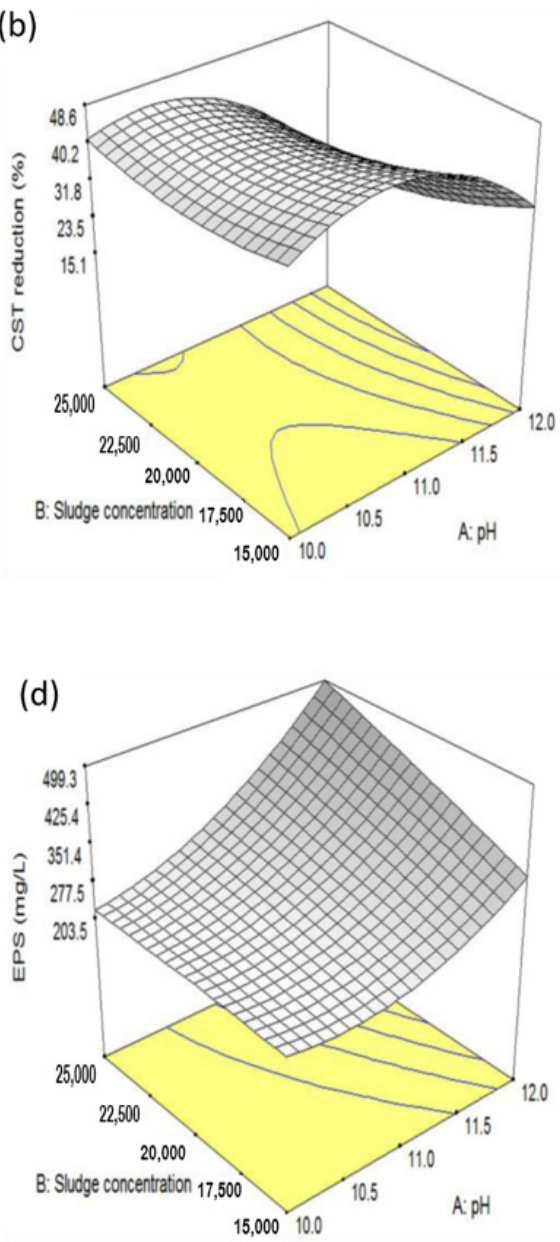

Figure 1. Three-dimensional response surface plots of (a) MLVSS removal; (b) CST reduction; (c) SCOD and (d) EPS between $\mathrm{pH}$ and sludge concentration. 
Table 3 shows important statistical parameters for the model, i.e., F values, adequate precision (AP), probability of lack-of-fit (PLOF) and $\mathrm{R}^{2}$ values.

Table 3. ANOVA for response surface quadratic model.

\begin{tabular}{ccccc}
\hline Response & Model (F Value) & PLOF & AP & $\mathbf{R}^{\mathbf{2}}$ \\
\hline MLVSS removal (\%) & 0.0002 & 0.0126 & 11.393 & 0.8759 \\
sCOD & $<0.0001$ & 0.0059 & 11.544 & 0.9016 \\
CST reduction (\%) & $<0.0001$ & 0.0055 & 15.074 & 0.8867 \\
EPS & $<0.0001$ & 0.0944 & 14.096 & 0.9199 \\
\hline
\end{tabular}

In this study, p-values of the examined models were $<0.0002$; showing that the models were statistically significant $(p<0.05)$ for the four responses. A lack-of-fit test is used to see how well a model fits the data. The probability of lack-of-fit (PLOF) should be insignificant $(p>0.05)$ for a good fit, such as that demonstrated by EPS in this study. Nonetheless, a data set that has a statistically significant model with simultaneous momentous lack of fit can happened. This can be rationalized when the center points are fitting better than the model points, which could ultimately trigger a significant lack of fit (LOF) statistic [42]. Additionally, the optimal operating condition proposed by the model can be employed to further verify applicability of the results. Adequate precision (AP) indicates the ratio of signal to noise. All the responses had $\mathrm{AP}>4$, indicating that an adequate signal has been obtained. Thus, the models can be used to navigate the design space [43]. The R2 coefficient provides a further verification of the responses variation between the observed and predicted values by the models. $\mathrm{R}^{2}$ value close to 1 indicates that experimental data are highly correlated with prediction of the model, and it should be at least 0.8 for a good fit [44]. The $\mathrm{R}^{2}$ values in this study were therefore acceptable. The ANOVA statistical results indicate that the model prediction for sludge disintegration and dewaterability are of sufficient precision.

Representative response surface plots showing the effect of $\mathrm{pH}$ and sludge concentration on MLVSS removal, CST reduction, sCOD and EPS concentrations at 30 min electrolysis time and $7.5 \mathrm{~mA} / \mathrm{cm}^{2}$ current density are presented in Figure 1. The maximum MLVSS removal, CST reduction, sCOD, and minimum EPS were $28.6 \%, 48.6 \%, 7310 \mathrm{mg} / \mathrm{L}$, and $499 \mathrm{mg} / \mathrm{L}$, respectively, at $\mathrm{pH} 10.5-12$ and sludge concentration of 20,000-25,000 mg/L. Figure 1 shows that MLVSS removal, sCOD, and EPS increased with the increment in $\mathrm{pH}$. With addition of alkaline, the surfaces of bacteria had more negative charges, which cause enhanced sludge disintegration and desorption of EPS, due to higher electrostatic repulsion [45]. Consequently, the cellular substances were disintegrated, releasing sCOD and EPS to the aqueous phase. Many studies have used changes in SCOD concentration as an indication of sludge treatment efficiency in terms of solubilization $[46,47]$. Significant sCOD increment indicates that WAS disintegrated effectively through the electrochemical pre-treatment. However, sludge dewaterability would deteriorate with increment in EPS concentration, thus affecting the CST reduction. The figure shows that the highest CST reduction was at about $48.6 \%$ at $\mathrm{pH} 11$. Further increment in $\mathrm{pH}$ did not improve the CST. The concentrations of sCOD and EPS increased with the increment in sludge concentration but had minor effect on CST reduction. This may be attributed to increment in sludge concentration that increases the EPS, which consequently balanced out or even deteriorated the CST reduction. Generally, MLVSS removal and EPS increased whereas sCOD decreased with the increase in electrolysis time while CST reduction was not appreciably affected by the electrolysis time. With time, sludge solubilization increased as more sludge cells were disintegrated. CST reduction, and the concentrations of SCOD and EPS increased with the increase in current density as more electrons passing through the circuit increased the rate of oxidation at the anode. 


\subsubsection{Process Optimization by Response Surface Methodology (RSM)}

The four operating parameters were optimized due to the inherent trade-off relationship between them. In order to meet the objective of maximizing MLVSS removal, sCOD concentration, and CST reduction while minimizing EPS concentration, the response limits were set for each parameter by adjusting the minimum or maximum permissible values in the Design Expert software, viz. minimum MLVSS removal 24\%, minimum sCOD $6000 \mathrm{mg} / \mathrm{L}$, minimum CST reduction $28 \%$, and maximum EPS $400 \mathrm{mg} / \mathrm{L}$, as depicted in Figure 2 .

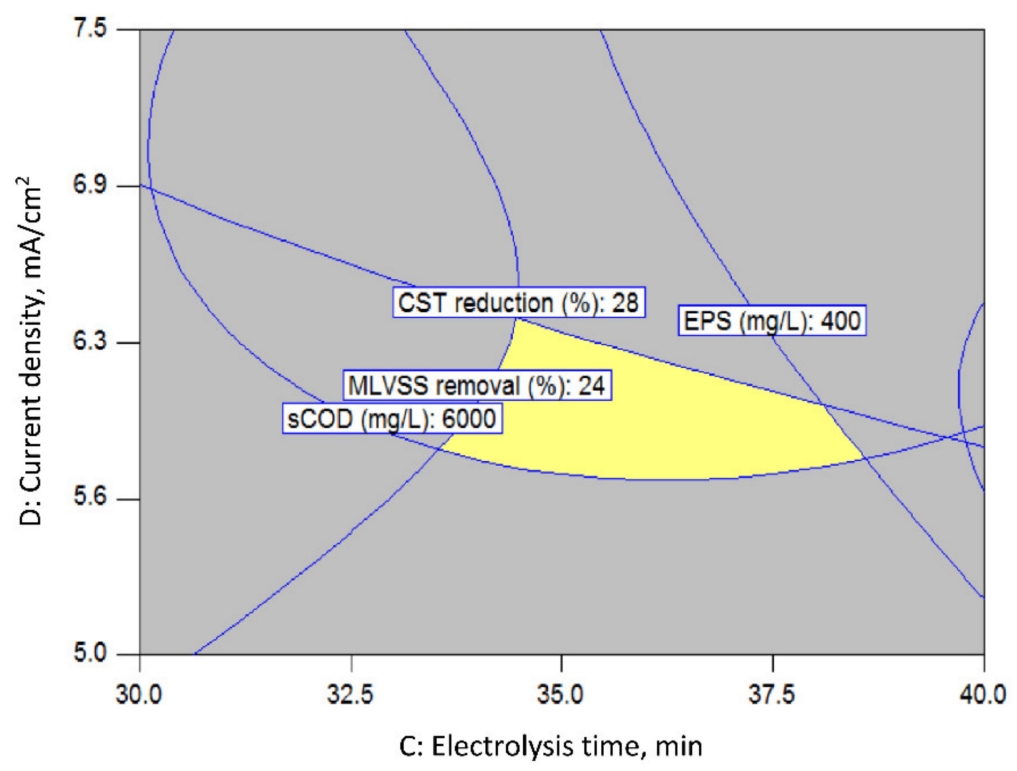

Figure 2. Overlay plot for optimal region at $\mathrm{pH} 11.65$ and sludge concentration 22,000 mg/L.

The shaded region in the overlay plot shows the optimum parameters- $\mathrm{pH} 11.65$, sludge concentration 22,000 $\mathrm{mg} / \mathrm{L}$, electrolysis time $35 \mathrm{~min}$ and current density $6 \mathrm{~mA} / \mathrm{cm}^{2}$. It is in good agreement with Yuan et al. [35], who reported the CST of WAS was reduced by $25.2 \%$ after electrochemical pre-treatment. Another study demonstrated that the MLVSS removal was increased with longer electrolysis time and greater electric power but decreased with higher initial sludge concentration [13]. However, the MLVSS removal was much lower $(7.87 \%)$ with sludge concentration of $12.9 \mathrm{~g} / \mathrm{L}, \mathrm{pH} 10$ and electrolysis time $30 \mathrm{~min}$, compared to the current study.

Electrolyte was added under optimum operating conditions to further enhance the efficiency of the $\mathrm{Ti} / \mathrm{RuO}_{2}$ electrochemical pre-treatment. It has been reported that chloride as supporting electrolyte would result in more effective degradation on $\mathrm{MMO}$ anodes such as $\mathrm{Ti} / \mathrm{RuO}_{2}[48,49]$. It is noticeable that by applying $1000 \mathrm{mg} / \mathrm{L}$ of sodium chloride $(\mathrm{NaCl})$, the MLVSS removal was significantly increased from 18 to $37.9 \%$ and CST reduction from 24.8 to $32.7 \%$, but no further increment was observed at higher concentrations of $\mathrm{NaCl}$ (Figure 3). Hence, the formation of additional oxidizing species (hypochlorite ion) that could further break down WAS is inferred [50]. It was also noted that with the addition of 500 to $2000 \mathrm{mg} / \mathrm{L} \mathrm{NaCl}$, there was about 15\% increase in sCOD concentration while EPS concentration was hardly affected. 


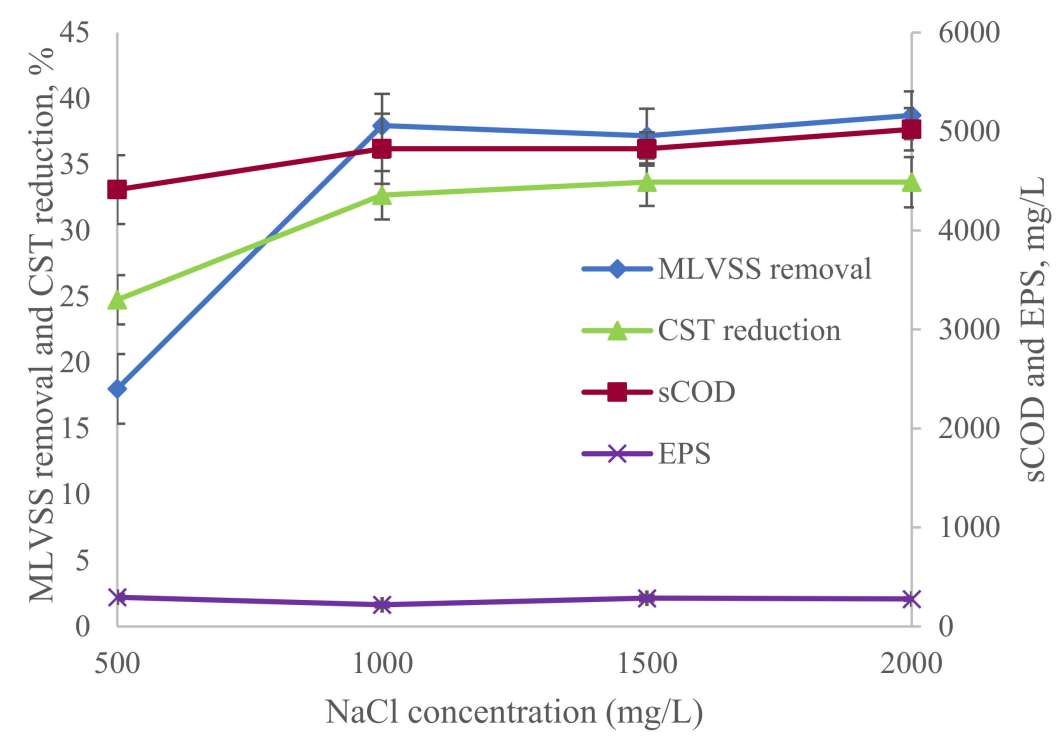

Figure 3. The effect of $\mathrm{NaCl}$ on MLVSS removal, CST reduction, sCOD, and EPS concentrations.

\subsection{Anaerobic Digester Performance}

Mesophilic anaerobic digestion of raw (control) and pre-treated WAS were carried out to determine the suitability of electrochemical oxidation as a pre-treatment option for application in biogas production. The control and pre-treated sludge were fed to the digesters for processing with $15 \mathrm{~d}$ SRT. After three cycles of digestion, steady-state operation was attained with variations in decrement of COD being observed to be $<10 \%$ consistently. To verify the effectiveness of electrochemical pre-treatment, COD removal, VS removal, and biogas production were used as the indicators of sludge digest-ability enhancement.

During digestion, COD is measured and regarded as one of the parameters that describes solubilization extend of the organic matter [51]. Figure 4 shows the changes in COD concentrations of both electrochemically pre-treated WAS fed and the control reactors during anaerobic digestion for four cycles. Both digesters showed similar trend as COD decreased in first three cycles and achieved steady-state after 45 days. The average effluent COD concentrations of electrochemically pre-treated WAS fed and the control reactors were 20,494 and $24,155 \mathrm{mg} / \mathrm{L}$, respectively. The lower concentration of COD in pre-treated WAS showed more organic matter was solubilized into degradable form. The average COD removal from the pre-treated WAS fed and the control reactors was 61.5 and $54.7 \%$, respectively.

According to USEPA Standards for the Use or Disposal of Sewage Sludge [36], a minimum of $38 \%$ VS removal has to be achieved for effective stabilization of sewage sludge. The VS reduction in control was higher when compared to the pre-treated WAS after digestion giving a reduction of $40.7 \%$, compared to $34.5 \%$. In a digestion system incorporating a pre-treatment, a substantial fraction of the organic matter is solubilized before the sludge reaches the anaerobic digester. This fraction should be included when calculating the overall solids reduction by the sludge treatment system. Thus, the total VS reduction in the WAS with pre-treatment was $47.2 \%$; which is greater than $40.7 \%$ (control). The results corresponded well with those reported by Xu et al. [52], that states final VS removal of electrochemical pre-treated-anaerobic digested WAS at day 45 was $45.5 \%$, whereas $38.9 \%$ was achieved in the control. 


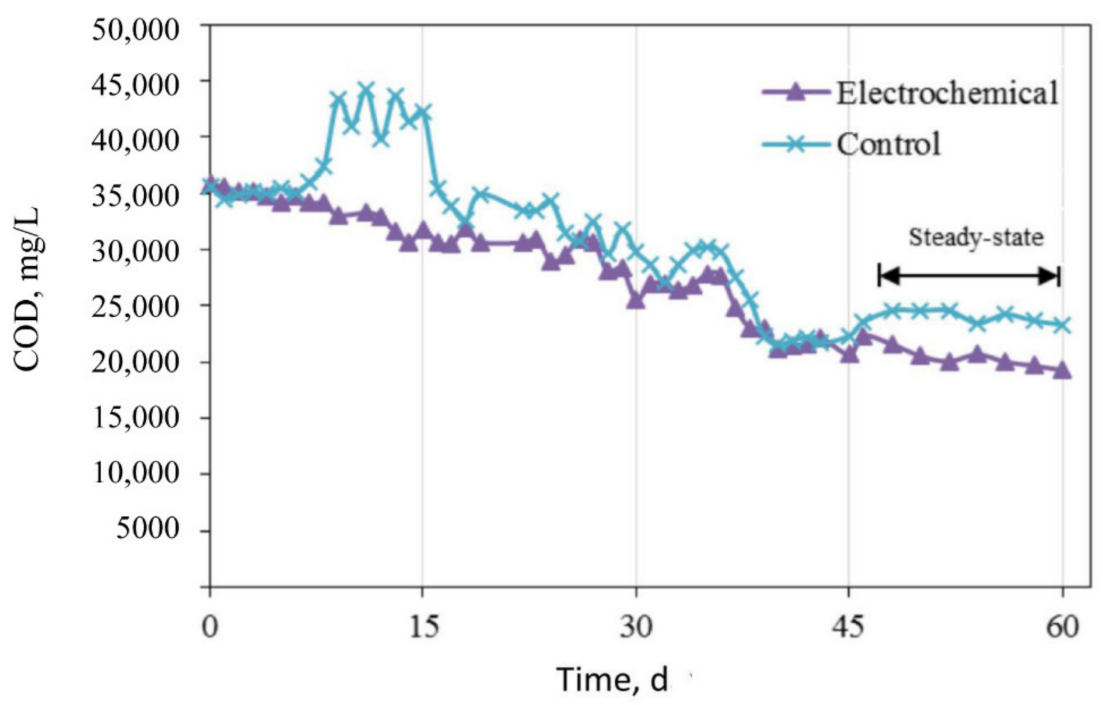

Figure 4. COD concentrations during anaerobic digestion of electrochemically pre-treated WAS and control.

The methane component of the biogas from electrochemically pre-treated WAS and control was $65.4 \pm 2.8 \%$ and $64.8 \pm 3.3 \%$, respectively, at steady-state. It agreed well with the average methane composition of $63 \%$ for conventional anaerobic digestion [53]. The average biogas production of the control at steady-state was $0.12-0.17 \mathrm{~m}^{3} / \mathrm{kg} \mathrm{VS}$ fed (Figure 5) in accordance with typical WAS digestion $\left(0.15-0.30 \mathrm{~m}^{3} / \mathrm{kg} \mathrm{VS}_{\mathrm{fed}}\right)$ [54]. The pre-treated WAS fed anaerobic digester accelerated biogas production to $0.2-0.24 \mathrm{~m}^{3} / \mathrm{kg}$ $\mathrm{VS}_{\text {fed, }}$ which was about $42 \%$ higher than the control. This is because pre-treatment of WAS hydrolyzed a part of the organic matter into soluble forms, and improved digestion efficiency. In recent studies, biogas production by electrochemical pre-treated-anaerobic digestion system has been reported to be about $60 \%$ higher than in control [26,52]. However, the difference in results is probably due to different operating conditions in electrochemical pre-treatment (e.g., greater effective electrode area, smaller distance between electrodes, etc.), which will eventually affect the performance of the anaerobic reactor.

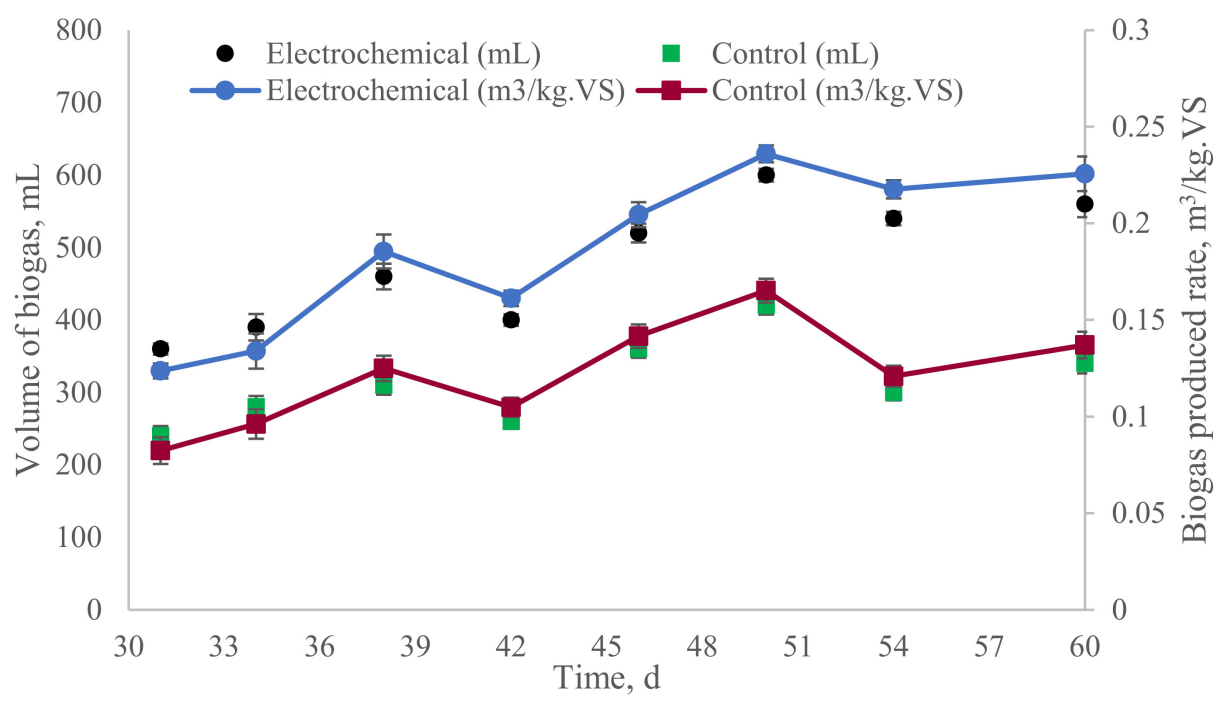

Figure 5. Volume and rate of biogas production during anaerobic digestion of WAS by electrochemical pre-treatment and control. 


\section{Conclusions}

RSM was used to model and optimize electrochemical pre-treatment of WAS using $\mathrm{Ti} / \mathrm{RuO}_{2}$ electrodes. The optimum operating variables were $\mathrm{pH} 11.65$, sludge concentration 22,000 mg/L, electrolysis time $35 \mathrm{~min}$ and current density $6 \mathrm{~mA} / \mathrm{cm}^{2}$ aided with $1000 \mathrm{mg} / \mathrm{L}$ sodium chloride to achieve MLVSS removal 38\%, CST reduction 33\%, sCOD $6000 \mathrm{mg} / \mathrm{L}$ and EPS $400 \mathrm{mg} / \mathrm{L}$. Electrochemical pre-treatment has the capability to improve WAS disintegration and dewaterability by increasing the soluble organic fraction or $\mathrm{SCOD}$, and at the same time reducing solids concentration and CST. In addition, via operation at optimal operating condition, WAS anaerobic digestion has been substantially improved via the electrochemical pre-treatment step, viz. $47.2 \%$ total VS reduction, $61.5 \%$ COD removal and $0.2-0.24 \mathrm{~m}^{3} / \mathrm{kg}$ VS.d biogas production rate; compared to $40.7 \%$ total VS solids reduction, $54.7 \%$ COD removal and $0.12-0.17 \mathrm{~m}^{3} / \mathrm{kg}$ VS. $\mathrm{d}$ biogas production rate for control. It has also been demonstrated in this study that the integration of the optimally operated electrochemical-anaerobic digestion system as a WAS pre-treatment strategy is able to improve production rate and capacity of biogas by $44-67 \%$ in comparison to conventional process using mere anaerobic digestion. The electrochemical-anaerobic digestion system provides a better-quality effluent and enhances biogas production. The RSM models and optimal operating condition obtained in this study is important to gain sufficient insight underlying the process in order to be applied in subsequent improvement studies dedicated to WAS treatment using $\mathrm{Ti} / \mathrm{RuO}_{2}$ electrodes. It is hopeful that scale-up of this electrochemical treatment WAS in actual industrial application with large capacity can be ultimately achieved via this information. Nonetheless, for the electrochemical pre-treatment to achieve maturation for commercialization and be fully economical viable, more research works have to be conducted typically at larger scale. However, it is of high potential considering that it has been demonstrated in this study that optimization of important process variables is able to enhance sludge digestibility and biogas production. In addition, the RSM models can be used in process automation and control of the wastewater treatment systems for more feasible implementation of the application in industrial process.

Supplementary Materials: The following are available online at https:/ / www.mdpi.com/article/10 .3390/su13094874/s1, Table S1: ANOVA for MLVSS removal (Y1) quadratic model, Table S2: ANOVA for CST reduction (Y2) quadratic model, Table S3: ANOVA for SCOD (Y3) quadratic model, Table S4: ANOVA for EPS (Y4) quadratic model.

Author Contributions: Conceptualization: G.C.H., M.H.I.; Formal analysis: G.C.H., M.H.I., S.S.M.L.; Methodology: G.C.H., M.H.I.; Supervision: M.H.I.; Visualization: S.S.M.L., C.A.N.; Writing—original draft: G.C.H.; Writing—review and editing: M.H.I., S.S.M.L., C.A.N. All authors have read and agreed to the published version of the manuscript.

Funding: This research was funded by Universiti Tunku Abdul Rahman (UTAR), Malaysia through UTAR Research Fund under project number IPSR/RMC/UTARRF/2019-C1/G01. The APC was funded by UTAR and Universiti Teknologi PETRONAS (UTP), Malaysia.

Institutional Review Board Statement: Not applicable.

Informed Consent Statement: Not applicable.

Data Availability Statement: The data presented in this study are available on request from the corresponding author.

Acknowledgments: The authors are thankful to UTAR and UTP for providing facilities and support for this research.

Conflicts of Interest: The authors declare no conflict of interest. 


\section{References}

1. Tezel, U.; Tandukar, M.; Pavlostathis, S.G. Anaerobic Biotreatment of Municipal Sewage Sludge. In Comprehensive Biotechnology, 2nd ed.; Agathos, S., Ed.; Environmental Biotechnology and Safety; Elsevier: Amsterdam, The Netherlands, 2011 ; Volume 6.

2. Mininni, G.; Laera, G.; Bertanza, G.; Canato, M.; Sbrilli, A. Mass and energy balances of sludge processing in reference and upgraded wastewater treatment plants. Environ. Sci. Pollut. Res. 2015, 22, 7203-7215. [CrossRef]

3. Tomei, M.C.; Bertanza, G.; Canato, M.; Heimersson, S.; Laera, G.; Svanström, M. Techno-economic and environmental assessment of upgrading alternatives for sludge stabilization in municipal wastewater treatment plants. J. Clean Prod. 2016, 112, 3106-3115. [CrossRef]

4. Gu, Y.; Li, Y.; Li, X.; Luo, P.; Wang, H.; Wang, X.; Wu, J.; Li, F. Energy Self-sufficient Wastewater Treatment Plants: Feasibilities and Challenges. Energy Procedia 2017, 105, 3741-3751. [CrossRef]

5. Carrère, H.; Dumas, C.; Battimelli, A.; Batstone, D.; Delgenès, J.; Steyer, J.; Ferrer, I. Pretreatment methods to improve sludge anaerobic degradability: A review. J. Hazard. Mater. 2010, 183, 1-15. [CrossRef]

6. Sheng, G.-P.; Yu, H.-Q.; Li, X.-Y. Extracellular polymeric substances (EPS) of microbial aggregates in biological wastewater treatment systems: A review. Biotechnol. Adv. 2010, 28, 882-894. [CrossRef] [PubMed]

7. Wingender, J.; Jäger, K.E.; Flemming, H.-C. Interaction between extracellular polysaccharides and enzymes. In Microbial Extracellular Polymeric Substances; Wingender, J., Neu, T.R., Eds.; Springer: Berlin/Heidelberg, Germany, 1999; pp. 1-19.

8. Forster, C.F. Bound water in sewage sludges and its relationship to sludge surfaces and sludge viscosities. J. Chem. Technol. Biotechnol. 2008, 33, 76-84. [CrossRef]

9. Roberson, E.B.; Firestone, M.K. Relationship between Desiccation and Exopolysaccharide Production in a Soil Pseudomonas sp. Appl. Environ. Microbiol. 1992, 58, 1284-1291. [CrossRef]

10. Chen, Z.; Zhang, W.; Wang, D.; Ma, T.; Bai, R. Enhancement of activated sludge dewatering performance by combined composite enzymatic lysis and chemical re-flocculation with inorganic coagulants: Kinetics of enzymatic reaction and re-flocculation morphology. Water Res. 2015, 83, 367-376. [CrossRef] [PubMed]

11. Heng, G.C.; Isa, M.H.; Lim, J.-W.; Ho, Y.-C.; Zinatizadeh, A.A.L. Enhancement of anaerobic digestibility of waste activated sludge using photo-Fenton pretreatment. Environ. Sci. Pollut. Res. 2017, 24, 27113-27124. [CrossRef]

12. Kavitha, S.; Saranya, T.; Kaliappan, S.; Kumar, S.A.; Yeom, I.T.; Banu, J.R. Accelerating the sludge disintegration potential of a novel bacterial strain Planococcus jake 01 by CaCl2 induced deflocculation. Bioresour. Technol. 2015, 175, 396-405. [CrossRef]

13. Song, L.-J.; Zhu, N.-W.; Yuan, H.-P.; Hong, Y.; Ding, J. Enhancement of waste activated sludge aerobic digestion by electrochemical pre-treatment. Water Res. 2010, 44, 4371-4378. [CrossRef] [PubMed]

14. Sanin, F.D.; Vesilind, P.A. Effect of centrifugation on the removal of extracellular polymers and physical properties of activated sludge. Water Sci. Technol. 1994, 30, 117-127. [CrossRef]

15. Karr, P.R.; Keinath, T.M. Influence of particle size on sludge dewatering. J. Water Pollut. Control. Fed. 1978, 50, 1911-1930.

16. Trasatti, S. Electrocatalysis: Understanding the success of DSA®. Electrochim. Acta 2000, 45, 2377-2385. [CrossRef]

17. Malpass, G.; Miwa, D.; Mortari, D.; Machado, S.; Motheo, A. Decolorisation of real textile waste using electrochemical techniques: Effect of the chloride concentration. Water Res. 2007, 41, 2969-2977. [CrossRef]

18. Yaqub, A.; Isa, M.H.; Ajab, H. Electrochemical Degradation of Polycyclic Aromatic Hydrocarbons in Synthetic Solution and Produced Water Using a Ti/SnO2-Sb2O5-RuO2 Anode. J. Environ. Eng. 2015, 141, 04014074. [CrossRef]

19. Santos, I.D.; Dezotti, M.; Dutra, A.J. Electrochemical treatment of effluents from petroleum industry using a Ti/RuO2 anode. Chem. Eng. J. 2013, 226, 293-299. [CrossRef]

20. Kim, S.; Kim, T.-H.; Park, C.; Shin, E.-B. Electrochemical oxidation of polyvinyl alcohol using a $\mathrm{RuO}_{2} / \mathrm{Ti}$ anode. Desalination 2003, 155, 49-57. [CrossRef]

21. Torresa, R.A.; Sarria, V.; Torres, W.; Peringera, P.; Pulgarina, C. Electrochemical treatment of industrial wastewater containing 5-amino-6-methyl-2-benzimidazolone: Toward an electrochemical-biological coupling. Water Res. 2003, 37, 3118-3124. [CrossRef]

22. Martínez-Huitle, C.A.; Brillas, E. Decontamination of wastewaters containing synthetic organic dyes by electrochemical methods: A general review. Appl. Catal. B Environ. 2009, 87, 105-145. [CrossRef]

23. Costa, C.R.; Botta, C.M.; Espíndola, E.L.; Olivi, P. Electrochemical treatment of tannery wastewater using DSA®electrodes. J. Hazard. Mater. 2008, 153, 616-627. [CrossRef]

24. Simond, O.; Schaller, V.; Comninellis, C. Theoretical model for the anodic oxidation of organics on metal oxide electrodes. Electrochim. Acta 1997, 42, 2009-2012. [CrossRef]

25. Heng, G.C.; Isa, M.H. Electrochemical Disintegration of Activated Sludge Using Ti/RuO2 Anode. Appl. Mech. Mater. 2014, 567, 44-49. [CrossRef]

26. Yu, B.; Xu, J.; Yuan, H.; Lou, Z.; Lin, J.; Zhu, N. Enhancement of anaerobic digestion of waste activated sludge by electrochemical pretreatment. Fuel 2014, 130, 279-285. [CrossRef]

27. Ye, C.; Yuan, H.; Lou, Z.; Zhu, N. Combined Electrochemical and Hypochlorite Pretreatment for Improving Solubilization and Anaerobic Digestion of Waste-Activated Sludge: Effect of Hypochlorite Dosage. Energy Fuels 2016, 30, 2990-2996. [CrossRef]

28. Erden, G. Disintegration of Biological Sludge by Electro-oxidation Process with Different Electrode Couples. Waste Biomass Valorization 2019, 11, 2701-2707. [CrossRef]

29. Ajab, H.; Isa, M.H.; Yaqub, A. Electrochemical oxidation using ti/RuO2 anode for COD and PAHs removal from aqueous solution. Sustain. Mater. Technol. 2020, 26, e00225. [CrossRef] 
30. Yuan, H.; Yu, B.; Cheng, P.; Zhu, N.; Yin, C.; Ying, L. Pilot-scale study of enhanced anaerobic digestion of waste activated sludge by electrochemical and sodium hypochlorite combination pretreatment. Int. Biodeterior. Biodegrad. 2016, 110, 227-234. [CrossRef]

31. Ding, W.; Jin, W.; Zhou, X.; Yang, Q.; Chen, C.; Wang, Q. Role of extracellular polymeric substances in anaerobic granular sludge: Assessing dewaterability during Fe(II)-peroxydisulfate conditioning and granulation processes. J. Clean. Prod. 2020, $286,124968$. [CrossRef]

32. Box, G.E.P.; Wilson, K.B. On the experimental attainment of optimum conditions. J. R. Stat. Soc. Ser. B 1951, 13, 1-45. [CrossRef]

33. Preece, D.A.; Montgomery, D.C. Design and Analysis of Experiments. Int. Stat. Rev. 1978, 46, 120. [CrossRef]

34. Rodrigues, E.; Olivi, P. Preparation and characterization of Sb-doped $\mathrm{SnO}_{2}$ films with controlled stoichiometry from polymeric precursors. J. Phys. Chem. Solids 2003, 64, 1105-1112. [CrossRef]

35. Yuan, H.; Zhu, N.; Song, F. Dewaterability characteristics of sludge conditioned with surfactants pretreatment by electrolysis. Bioresour. Technol. 2011, 102, 2308-2315. [CrossRef]

36. USEPA. Standards for the Use or Disposal of Sewage Sludge. In 40CFR PART 503; United States Environmental Protection Agency: Washington, DC, USA, 1993.

37. APHA. Standard Methods for the Examination of Water and Wastewater; American Public Health Association: Washington, DC, USA, 2005.

38. HACH. Water Analysis Handbook, 4th ed.; Hach Company: Loveland, CO, USA, 2003.

39. Ras, M.; Girbal-Neuhauser, E.; Paul, E.; Spérandio, M.; Lefebvre, D. Protein extraction from activated sludge: An analytical approach. Water Res. 2008, 42, 1867-1878. [CrossRef] [PubMed]

40. Zuriaga-Agustí, E.; Bes-Piá, A.; Mendoza-Roca, J.; Alonso-Molina, J. Influence of extraction methods on proteins and carbohydrates analysis from MBR activated sludge flocs in view of improving EPS determination. Sep. Purif. Technol. 2013, 112, 1-10. [CrossRef]

41. Ammar, A.A.; Asmeret, A.B.; Teamrat, A.G. A new method for rapid determination of carbohydrate and total carbon concentrations using UV spectrophotometry. Carbohydr. Polym. 2013, 97, 253-261.

42. SHARI. FAQ_-Interpreting Lack of Fit; Stat-Teaser, News from Stat-Ease, Inc.: Minneapolis, MN, USA, 2004.

43. Mohajeri, S.; Aziz, H.A.; Isa, M.H.; Zahed, M.A.; Bashir, M.J.K.; Adlan, M.N. Application of the central composite design for condition optimization for semi-aerobic landfill leachate treatment using electrochemical oxidation. Water Sci. Technol. 2010, 61, 1257-1266. [CrossRef]

44. Ölmez, T. The optimization of $\mathrm{Cr}(\mathrm{VI})$ reduction and removal by electrocoagulation using response surface methodology. J. Hazard. Mater. 2009, 162, 1371-1378. [CrossRef]

45. Katsiris, N.; Kouzeli-Katsiri, A. Bound water content of biological sludges in relation to filtration and dewatering. Water Res. 1987, 21, 1319-1327. [CrossRef]

46. Apul, O.G.; Atalar, I.; Zorba, G.T.; Sanin, F.D. The Dewaterability of Disintegrated Sludge Samples before and after Anaerobic Digestion. Dry. Technol. 2010, 28, 901-909. [CrossRef]

47. Chen, Y.; Jiang, S.; Yuan, H.; Zhou, Q.; Gu, G. Hydrolysis and acidification of waste activated sludge at different pHs. Water Res. 2007, 41, 683-689. [CrossRef] [PubMed]

48. Costa, C.R.; Olivi, P. Effect of chloride concentration on the electrochemical treatment of a synthetic tannery wastewater. Electrochim. Acta 2009, 54, 2046-2052. [CrossRef]

49. Scialdone, O.; Randazzo, S.; Galia, A.; Silvestri, G. Electrochemical oxidation of organics in water: Role of operative parameters in the absence and in the presence of $\mathrm{NaCl}$. Water Res. 2009, 43, 2260-2272. [CrossRef]

50. Feng, Y.; Smith, D.W.; Bolton, J.R. Photolysis of Aqueous Free Chlorine Species $\left(\mathrm{HOCl}_{\text {and OCl}}{ }^{-}\right)$with $254 \mathrm{~nm} \mathrm{Ultraviolet} \mathrm{Light.}$ J. Environ. Eng. Sci. 2007, 6, 277-284. [CrossRef]

51. Bougrier, C.; Albasi, C.; Delgenès, J.; Carrère, H. Effect of ultrasonic, thermal and ozone pre-treatments on waste activated sludge solubilisation and anaerobic biodegradability. Chem. Eng. Process. 2006, 45, 711-718. [CrossRef]

52. Xu, J.; Yuan, H.; Lin, J.; Yuan, W. Evaluation of thermal, thermal-alkaline, alkaline and electrochemical pretreatments on sludge to enhance anaerobic biogas production. J. Taiwan Inst. Chem. Eng. 2014, 45, 2531-2536. [CrossRef]

53. Appels, L.; Baeyens, J.; Degrève, J.; Dewil, R. Principles and potential of the anaerobic digestion of waste-activated sludge. Prog. Energy Combust. Sci. 2008, 34, 755-781. [CrossRef]

54. Braguglia, C.M.; Gianico, A.; Gallipoli, A.; Mininni, G. The impact of sludge pre-treatments on mesophilic and thermophilic anaerobic digestion efficiency: Role of the organic load. Chem. Eng. J. 2015, 270, 362-371. [CrossRef] 